\title{
Efficacy of a Broad Host Range Lytic Bacteriophage Against E. coli Adhered to Urothelium
}

\author{
Sanna Sillankorva $\cdot$ Dulce Oliveira $\cdot$ \\ Alexandra Moura $\cdot$ Mariana Henriques · \\ Alberta Faustino $\cdot$ Ana Nicolau · Joana Azeredo
}

Received: 24 September 2010/ Accepted: 22 November 2010/Published online: 8 December 2010

(C) Springer Science+Business Media, LLC 2010

\begin{abstract}
Persistent urinary tract infections (UTI) are often caused by E. coli adhered to urothelium. This type of cells is generally recognized as very tolerant to antibiotics which renders difficult the treatment of chronic UTI. This study investigates the use of lytic bacteriophages as alternative antimicrobial agents, particularly the interaction of phages with E. coli adhered to urothelium and specifically determines their efficiency against this type of cells. The bacterial adhesion to urothelium was performed varying the bacterial cell concentrations and the period and conditions (static, shaken) of adhesion. Three collection bacteriophages (T1, T4, and phiX174 like phages) were tested against clinical E. coli isolates and only one was selected for further infection experiments. Based on the lytic spectrum against clinical isolates and its ability to infect the highest number of antibiotic resistant strains, the T1like bacteriophage was selected. This bacteriophage caused nearly a $45 \%$ reduction of the bacterial population after $2 \mathrm{~h}$ of treatment. This study provides evidence that
\end{abstract}

S. Sillankorva $(\bowtie) \cdot$ D. Oliveira $\cdot$ A. Moura $\cdot$ M. Henriques ·

A. Nicolau · J. Azeredo

Department of Biological Engineering, University of Minho, Braga, Portugal

e-mail: s.sillankorva@deb.uminho.pt

\section{A. Moura}

Instituto Piaget, Escola Superior de Saúde Jean, Piaget/Vila

Nova de Gaia, Portugal

\section{A. Faustino}

São Marcos Hospital, Braga, Portugal bacteriophages are effective in controlling suspended and adhered cells and therefore can be a viable alternative to antibiotics to control urothelium- adhered bacteria.

\section{Introduction}

In the recent years, there has been a spread of multidrug resistant bacteria, including bacteria resistant to the last resort antibiotics [1]. Therefore, prevention and control of bacterial resistance requires new antimicrobial agents, the prudent use of existing ones, new vaccines and enhanced public health efforts to reduce transmission of bacterial resistance. Also, the use of bacteriophages as an alternative to antibiotherapy is again redrawing attention. A considerable number of publications demonstrate that phage preparations for veterinary purposes can efficiently control the bacterial loads in infected animals [2-5] and strongly supports the concept of phage therapy as an alternative or complementary strategy to antibiotherapy. Furthermore, orally administered phages have been recovered from the blood and physical fluids, including urine $[6,7]$ and phages administered by intraperitoneal injection have been detected in different organs, such as: liver, kidneys, spleen, lungs, muscles, brain, and blood [8]. Despite these attractive characteristics, there is limited information on phage infection of bacteria adhered to epithelial cells. The study described herein focuses the efficacy of phage to kill its target host when the last is found adhered to urothelium. For this, the efficacy of three DSMZ collection phages (T1, T4 and phiX174) against a pool of $69 \mathrm{E}$. coli strains isolated from urinary tract infections was studied and only the broadest host range phage was used to perform the infection experiments with suspended or urothelium adhered E. coli. 


\section{Materials and Methods}

Bacteria, Bacteriophage, and Media

The bacteriophages and respective hosts were purchased from the Deutsche Sammlung von Mikroorganismen und Zellkulturen (DSMZ), Germany. Both bacteriophages T1 (DSM 5801) and T4 (DSM 4505) have as host Escherichia coli DSM 613, while phage phiX174 (DSM 4497) has ashost E. coli DSM 13127. The media used for E. coli growth were either LB media or artificial urine $\left(0.65 \mathrm{gl}^{-1}\right.$ of Magnesium chloride hexahydrate, $0.65 \mathrm{~g} \mathrm{l}^{-1}$ of Calcium chloride monohydrated, $4.6 \mathrm{~g} \mathrm{l}^{-1}$ of sodium chloride, $2.3 \mathrm{~g} \mathrm{l}^{-1}$ of sodium sulfate, $0.65 \mathrm{~g} \mathrm{l}^{-1}$ of Sodium Citrate dihydrated, $0.20 \mathrm{~g} \mathrm{l}^{-1}$ of Disodium oxalate, $2.8 \mathrm{~g} \mathrm{l}^{-1}$ of potassium dihydrogen phosphate, $1.6 \mathrm{~g} \mathrm{l}^{-1}$ of potassium chloride, $2.0 \mathrm{~g} \mathrm{l}^{-1}$ of $\mathrm{NH} 4 \mathrm{Cl}, 12 \mathrm{~g} \mathrm{l}^{-1}$ of Urea, $1.1 \mathrm{~g} \mathrm{l}^{-1}$ of Creatinin, $0.1 \mathrm{~g} \mathrm{l}^{-1}$ of Tryptic Soy Broth (TSB)). Phages were propagated in MGC media $(5.0 \mathrm{~g} / \mathrm{l}$ of peptone, $3.0 \mathrm{~g} / \mathrm{l}$ of meet extract and $0.8 \mathrm{~g} / \mathrm{l}$ of $\mathrm{NaCl})$. The clinical isolates of $E$. coli used in this study, were isolated from patients with urinary tract infections.

Lytic Spectra of the Phages and Selection

of the Broadest Host Range Phage

The three phages (T1, T4, and phiX174) were tested against the 69 clinical $E$. coli isolates using the phage spot test procedure [9]. In brief, $3 \mathrm{ml}$ of MGC top-agar (MGC media with $0.6 \%$ agar) were added to $100 \mu \mathrm{l}$ overnight cultures of each clinical isolate and poured onto a dish containing MGC agar (MGC media with $1.2 \%$ agar). The agar was allowed to solidify after which $10 \mu \mathrm{l}$ each phage was spotted on the bacterial lawn of the different isolates. The drop was allowed to dry and the plates were incubated overnight at $37^{\circ} \mathrm{C}$. Phage sensitive E. coli showed clear or turbid areas where the phage solutions were spotted.

\section{Antibiotic Sensitivity Test}

The susceptibility of the $69 \mathrm{E}$. coli clinical isolates to eight antimicrobial agents was determined by the disc diffusion method on modified Mueller-Hinton II agar according to the European Committee on Antimicrobial Susceptibility Testing (EUCAST).

Stability of Phage in Artificial Urine

$100 \mu \mathrm{l}$ of $\mathrm{T} 1$ phage were added to $400 \mu \mathrm{l}$ of artificial urine and incubated at $37^{\circ} \mathrm{C}$ during $24 \mathrm{~h}$. Samples were taken after $0,3,6,9$, and $24 \mathrm{~h}$ and the phage titre was performed according to Adams [10].
Epithelial Cells and Growth Conditions

Epithelial cell line from human bladder (TCC-SUP from DSMZ) was grown on D-MEM, supplemented with $15 \%$ of fetal bovine serum (FBS, Gibco-Invitrogen) and $1 \%$ Streptomycin/Penicillin (Gibco-Invitrogen). Cells were grown in 24 well microplates at $37^{\circ} \mathrm{C}$ and $5 \%$ of $\mathrm{CO} 2$, until they reached an $80 \%$ of confluence. A number of $1 \times 105$ cells per well, determined by tripan blue exclusion staining, was achieved.

\section{E. coli Adhesion to Epithelial Cells}

The TCC-SUP epithelial cell monolayers were washed with phosphate buffered saline (PBS 0.1 M, pH 7.4). After, $500 \mu$ of $E$. coli 613 diluted suspensions (104 up to 109 $\mathrm{CFUml}^{-1}$ ) or $500 \mu \mathrm{l}$ of PBS (control), were added to each monolayer. Adhesion assays were performed during 30, 60, 120 , and $180 \mathrm{~min}$, at $37^{\circ} \mathrm{C}$ and under agitation (120 rpm). At each time point, the wells were washed three times with PBS, to remove unattached bacteria. Bacteria were enumerated by $\mathrm{CFU}$ determination, after tripsinization of epithelial cells. All experiments were carried out in triplicate.

Phage Infection of Urothelium Adhered and Suspended Bacteria

Urothelium was grown at $37^{\circ} \mathrm{C}$ in 24 well ELISA plates until a concentration of 105 cells/well, after which $E$. coli were allowed to adhere for $2 \mathrm{~h}$. Afterwards, the adhered bacteria were phageinfected during $2 \mathrm{~h}$ varying the MOI used (0.1 and 1) and varying also the phage infection conditions (static and dynamic). The plates were incubated at $37^{\circ} \mathrm{C}$ and the efficacy of phage infection was assessed through determination of the concentration of bacteria. Phage infection of exponential E. coli cultures were also performed in order to compare the lytic efficacy of adhered against suspended E. coli. All experiments were carried out in triplicate.

\section{Results}

Antibiotic and Bacteriophage Susceptibility of the 69 Clinical Isolates of $E$. Coli

The susceptibility of the 69 clinical E. coli isolates is presented in Fig. 1. The resistance profiles of the E. coli clinical isolates revealed that more than 60 percent of the strains were resistant to ampicillin (AMP). Furthermore, the strains were most susceptible to nitrofurantoin (FD) (Fig. 1). Based on these results, the 69 isolates were 


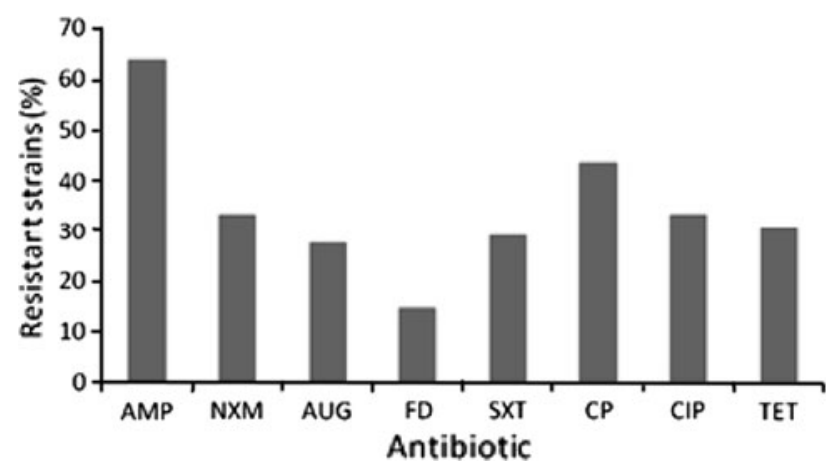

Fig. 1 Susceptibility of the 69 clinical E. coli isolates to 8 antibiotics (AMP ampicillin, NXM norfloxacin, $A U G$ amoxicillin/clavulanate, $F D$ nitrofurantoin, $S X T$ TMP-SMX, $C P$ cephalothin, $C I P$ ciprofloxacin, TET tetracycline)

divided in two groups: the first containing the resistant strains (Fig. 2a) and the second group containing the isolates susceptible to the antibiotics tested (Fig. 2b) and tested for susceptibility to three DSMZ culture collection phages: T1, T4, and phiX174, respectively. Phage T1 showed aptitude to infecting the highest percentage of antibiotic resistant E. coli strains (Fig. 2a) while phage T4 lysed a larger number of antibiotic susceptible isolates (Fig. 2b). Overall the $\mathrm{T} 1$ and $\mathrm{T} 4$ phages were the most efficient phages showing activity against 43.5 and $41.1 \%$ of the clinical isolates tested whereas phage phiX174 exhibited a narrower range of activity, being able to infect only $9.4 \%$ of the isolates tested. According to these results, phage $\mathrm{T} 1$ was selected for further experiments since it was capable of lysing the broadest range of hosts.

\section{Growth of E. coli and Stability of Phage T1 in Urine}

The growth characteristics of E. coli DSMZ 613, phage T1's host, in artificial urine were determined. This bacterium has a doubling time of approximately $53 \mathrm{~min}$ and a specific growth rate of $0.78 \mathrm{~h}^{-1}$. Stability tests performed with phage $\mathrm{T} 1$ in artificial urine showed that the phage remained stable for $24 \mathrm{~h}$ and maintained its infection ability, as confirmed by plaque forming unit tests performed after different periods of exposure to artificial urine (data not shown).

Phage Infection of Bacteria Suspended or Adhered to Urothelium

In vitro phage infection experiments of bacteria adhered to the urothelium were performed under static and dynamic (under the influence of shaking) conditions. Prior to the phage infection experiments on E. coli cells, the phage multiplicity of infection (MOI) was optimized. E. coli were infected, under dynamic conditions (120 rpm), with five different MOIs ranging from 0.01 up to 10 and cell lysis was followed by optical density measurements (data not shown). Two multiplicities of infection were selected for all further experiments: 0.1 and 1 , respectively and the infection period selected was $2 \mathrm{~h}$. Furthermore, two different $E$. coli concentrations which resulted in approximately $105 \mathrm{CFUml}^{-1}$ of adhered cells after $60 \mathrm{~min}$ were also selected for the adhesion and phage infection studies, 106 and $107 \mathrm{CFUml}^{-1}$, respectively (data not shown). It is important to have this concentration of adhered cells since typically a urinary tract infection is characterized by a positive uroculture of more than $105 \mathrm{CFUml}^{-1}[11,12]$. The reduction percentages of bacterial cells adhered to urothelium (A columns in Figs. 3, 4) following phage infection were compared with the reduction values obtained with suspended cultures (S columns in Figs. 3, 4). Under static conditions, cell reductions of both adhered and suspended bacteria following phage infection were in general very low. The use of different MOIs did not influence greatly the average reduction percentages obtained. However, it was clear that phages were slightly more efficient in lysing suspended E. coli than those found adhered to urothelium, independently on the inoculum concentration used. The higher inoculum concentration $\left(107 \mathrm{CFUml}^{-1}\right)$ resulted in a higher percentage of cell reduction clearly due to the presence of slightly more cells (a)

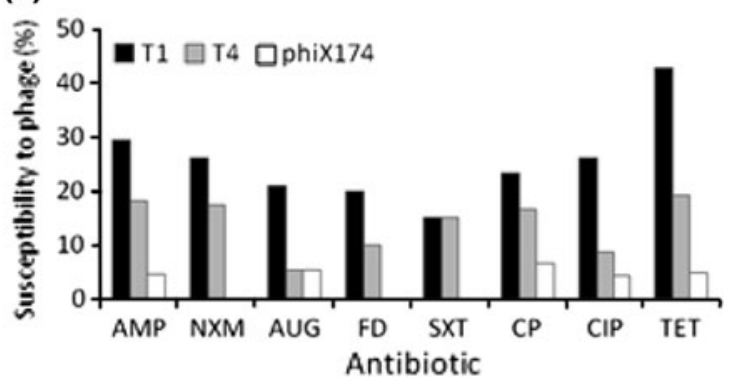

(b)

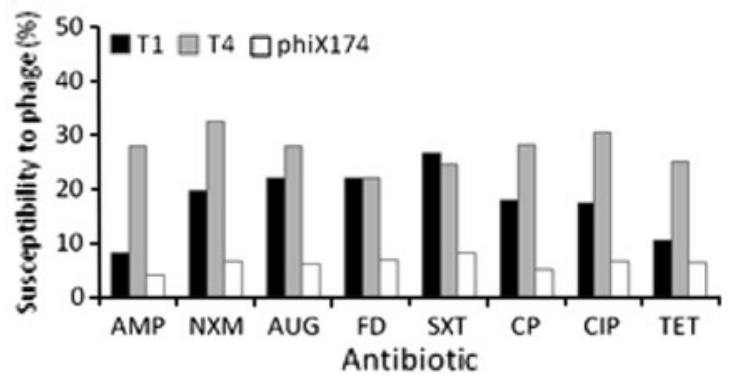

Fig. 2 Susceptibility of the 69 clinical E. coli isolates to bacteriophage T1, T4, and phiX174. Susceptibility of the: a antibiotic resistant and b antibiotic susceptible strains to phages 


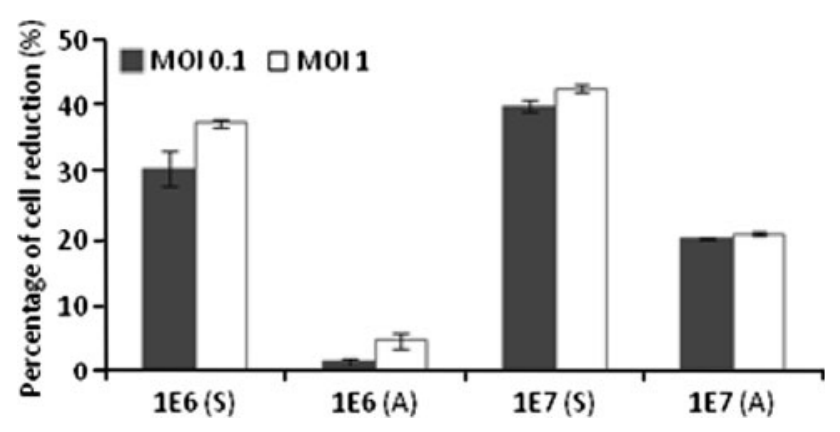

Fig. 3 Percentage of cell reduction after phage infection under static conditions of $E$. coli suspensions and cells adhered to urothelium using MOIs of 0.1 and 1. Phage infection was performed on bacterial suspensions (S) with two different concentrations (106 and 107 cellsml $^{-1}$ ) and on cells adhered (A) to urothelium for $2 \mathrm{~h}$ using inoculum concentrations of 106 and 107 cells ml $^{-1}$

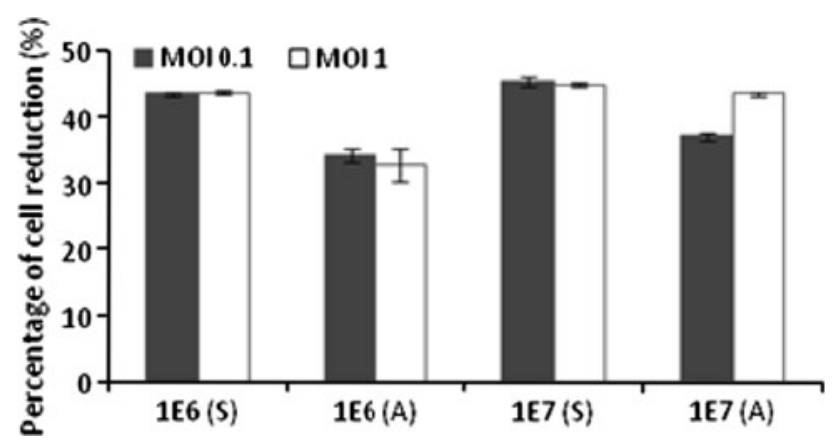

Fig. 4 Percentage of cell reduction after phage infection under dynamic conditions of $E$. coli suspensions and cells adhered to urothelium using MOIs of 0.1 and 1. Phage infection was performed on bacterial suspensions (S) with two different concentrations (106 and 107 cellsml $^{-1}$ ) and on cells adhered (A) to urothelium for $2 \mathrm{~h}$ using inoculum concentrations of 106 and 107 cellsml $^{-1}$

adhered to the urothelium than in the experiments where 106 $\mathrm{CFUml}^{-1}$ was used as inoculum. Although the reduction of adhered cells by phages under static conditions was low, this work evidences that phages can kill to some extent cells adhered to urothelium. Comparatively to the phage experiments carried out under static, under dynamic conditions the phage was significantly more efficient in infecting $E$. coli adhered to urothelium (Fig. 4). Under static infection conditions, the average cell reduction percentages obtained, using inoculum concentrations of 106 and $107 \mathrm{CFUml}^{-1}$, were approximately 10 and $20 \%$, while under dynamic conditions those percentages were about 30 and 35\% (compare Figs. 3, 4). Furthermore, like in the experiments performed under static conditions, the differences obtained using a MOI of 0.1 and 1.0 were insignificant.

\section{Discussion}

Urinary tract infections (UTI) are among the most common bacterial infections affecting a large proportion of the worldwide population. These infections are mainly caused by $E$. coli that have the capacity to colonize and invade epithelial cells [13]. Presumably, this tactic of invasion allows the development of a cellular niche where microorganism can persist in a protected pathway [14] especially against the action of the antibiotics, as already demonstrated both in vitro and in vivo $[15,16]$. In fact, the physiological alterations of bacteria triggered by the sessile mode of live can confer protection against antibiotics [17-19]. Specifically it has already been shown that bacteria adhered to epithelium can be up to 100 times more tolerant to antibiotics $[19,20]$. In this study the authors describe the use of bacteriophages to reduce the loads of E. coli adhered to urothelium and evaluate their efficacy after infection of cells using two different phage-host ratios and under two distinct conditions, static, and shaken, respectively. The results after the $2 \mathrm{~h}$ of phage treatment were similar using an initial MOI of 0.1 or 1 since both phage concentrations led to approximately the same percentage of cell reduction. Furthermore, phage T1 was significantly more efficient in infecting $E$. coli adhered to urothelium under shaken conditions most likely to an enhancement of the contact between the phage and the respective host. Contrarily to the infection of adhered E. coli, where the efficacy of phage T1 was affected by the application condition used (static or dynamic), the infection of planktonic cells with phage T1 under shaken and non-shaken conditions was comparable. Although in the present study, under static conditions, the adhered bacteria showed to be less sensitive to the phages overall the efficacy of phage T1 against adhered bacteria was similar to the infection of planktonic cells. Thus, contrarily to antibiotics, which hardly remove bacteria from existing biofilms [21], this study shows that phages are able to cause cell lysis of biofilm bacteria.

Besides the ability of phage T1 to infect adhered and planktonic E. coli cultures, this work also shows that phages deposited in culture collection have the ability to kill E. coli from different origins than the deposited host since it was able, together with T4 and phiX174, to infect a variety of antibiotic resistant clinical isolates.

\section{References}

1. Lepape A, Monnet DL (2009) Experience of European intensive care physicians with infections due to antibiotic-resistant bacteria. Euro Surveill 14:1-3

2. Atterbury RJ, Van Bergen MA, Ortiz F, Lovell MA, Harris JA, De BA, Wagenaar JA, Allen VM, Barrow PA (2007) Bacteriophage therapy to reduce salmonella colonization of broiler chickens. Appl Environ Microbiol 73:4543-4549

3. Huff WE, Huff GR, Rath NC, Donoghue AM (2006) Evaluation of the influence of bacteriophage titer on the treatment of colibacillosis in broiler chickens. Poult Sci 85:1373-1377 
4. Loc Carrillo C, Atterbury RJ, el-Shibiny A, Connerton PL, Dillon E, Scott A, Connerton IF (2005) Bacteriophage therapy to reduce Campylobacter jejuni colonization of broiler chickens. Appl Environ Microbiol 71:6554-6563

5. Wagenaar JA, Van Bergen MA, Mueller MA, Wassenaar TM, Carlton RM (2005) Phage therapy reduces Campylobacter jejuni colonization in broilers. Vet Microbiol 109:275-283

6. Krylov VN (2001) Phage therapy in terms of bacteriophage genetics: hopes prospects safety limitations. Russian J Genet 37:715-730

7. Weber-Dabrowska B, Dabrowski M, Slopek S (1987) Studies on bacteriophage penetration in patients subjected to phage therapy. Arch Immunol Ther Exp 35:563-568

8. Nishikawa H, Yasuda M, Uchiyama J, Rashel M, Maeda Y, Takemura I, Sugihara S, Ujihara T, Shimizu Y, Shuin T, Matsuzaki S (2008) T-even-related bacteriophages as candidates for treatment of Escherichia coli urinary tract infections. Arch Virol 153:507-515

9. Champagne CP, Gardner N (1995) The spot test method for the in-plant enumeration of bacteriophages with paired cultures of Lactobacillus delbrueckii subsp bulgaricus and Streptococcus salivarius subsp. thermophilus. Int Dairy J 5:417-425

10. Adams MH (1959) Bacteriophages. Interscience Publishers, New York

11. Domann E, Hong G, Imirzalioglu C, Turschner S, Kuhle J, Watzel C, Hain T, Hossain H, Chakraborty T (2003) Cultureindependent identification of pathogenic bacteria and polymicrobial infections in the genitourinary tract of renal transplant recipients. J Clin Microbiol 41:5500-5510

12. Pezzlo M (1988) Detection of urinary tract infections by rapid methods. Clin microbiol Rev 1:268-280

13. Healey MC, Hwang HH, Elsner YY, Johnston AV (1991) A model for demonstrating the adhesion of actinobacillus-seminis to epithelial-cells. Canadian J Veter Res 55:121-127
14. Finlay BB, Falkow S (1997) Common themes in microbial pathogenicity revisited. Microbiol Mol Biol Rev 61:136-139

15. Mulvey MA, Schilling JD, Hultgren SJ (2001) Establishment of a persistent Escherichia coli reservoir during the acute phase of a bladder infection. Infect Immun 69:4572-4579

16. Schilling JD, Lorenz RG, Hultgren SJ (2002) Effect of trimethoprim-sulfamethoxazole on recurrent bacteriuria and bacterial persistence in mice infected with uropathogenic Escherichia coli. Infect Immun 70:7042-7049

17. Cerca N, Martins S, Cerca F, Jefferson KK, Pier GB, Oliveira R, Azeredo J (2005) Comparative assessment of antibiotic susceptibility of coagulase-negative staphylococci in biofilm versus planktonic culture as assessed by bacterial enumeration or rapid XTT colorimetry. J Antimicrob Chemother 56:331-336

18. Cerca N, Martins S, Sillankorva S, Jefferson KK, Pier GB, Oliveira R, Azeredo J (2005) Effects of growth in the presence of subinhibitory concentrations of dicloxacillin on Staphylococcus epidermidis and Staphylococcus haemolyticus biofilms. Appl Environ Microbiol 71:8677-8682

19. Costa AR, Henriques M, Oliveira R, Azeredo J (2009) The role of polysaccharide intercellular adhesin (PIA) in Staphylococcus epidermidis adhesion to host tissues and subsequent antibiotic tolerance. Eur J Clin Microbiol Infect Dis 28:623-629

20. Ceri H, Olson ME, Stremick C, Read RR, Morck D, Buret A (1999) The calgary biofilm device: new technology for rapid determination of antibiotic susceptibilities of bacterial biofilms. J Clin Microbiol 37:1771-1776

21. Stewart PS, Costerton JW (2001) Antibiotic resistance of bacteria in biofilms. Lancet 358:135-138 